\title{
INDIKATOR SEKOLAH KREATIF
}

\author{
Riana Nurhayati \\ riana_nurhayati@uny.ac.id
}

Fakultas Ilmu Pendidikan, Universitas Negeri Yoyakarta

\begin{abstract}
Abstrak
Penelitian ini bertujuan untuk mengetahui indikator Sekolah Kreatif di Sekolah Dasar (SD). Penelitian ini menggunakan metode kualitatif. Subjek penelitian adalah kepala sekolah dan guru SD Muhammadiyah 16 Surabaya (Sekolah Kreatif). Analisa data dengan reduksi, kategorisasi dan intepretasi. Hasil penelitian menunjukkan bahwa indikator yang bisa dicapai oleh sekolah untuk membuat sekolah lebih kreatif adalah pengembangan sistem gagasan dan ide, pengembangan sistem sosial dalam aktivitas belajar, dan penciptaan sistem lingkungan sekolah yang sinergis antar unsur sekolah
\end{abstract}

Kata kunci: sekolah kreatif

\section{THE INDICATORS OF CREATIVE SCHOOL}

\author{
Riana Nurhayati \\ riana_nurhayati@uny.ac.id
}

Fakultas Ilmu Pendidikan, Universitas Negeri Yoyakarta

\begin{abstract}
This research is aimed at revealing the indicators of creative school in emelentary schools. The study employed qualitative method, and the subject of the research was the principal and teachers of Muhammadiyah 16 Surabaya Elementary School (a creative school). The data were analyzed by applying reduction, categorization, and interpretation. The result of the research shows that the indicators which can be attained by elementary school in order to contrive a creative school are developing the concept and idea systems, developing social system in learning activity, and creating synergetic school elements at the school environment system.
\end{abstract}

Keywords: creative school 


\section{PENDAHULUAN}

Indonesia merupakan negara berkembang yang masih terus berupaya memperbaiki kualitas pendidikannya. Upaya perbaikan sekolah terus dilakukan oleh pemerintah akan tetapi masih belum berhasil mengatasi masalah perbaikan kualitas atau mutu sekolah. Berbagai macam fenomena dan hasil penelitian maupun survei yang terjadi di Indonesia terutama yang berkaitan dengan permasalahan pendidikan yang terjadi di sekolah, sudah mulai dijadikan sebagai acuan dalam upaya perbaikan sekolah walaupun belum maksimal.

Realitasnya, ada beberapa hal yang menarik terutama yang berkaitan dengan adanya upaya perbaikan yang dilakukan oleh pihak sekolah maupun pengelola pendidikan, dimana sering melakukan banyak kesalahan dalam merancang perbaikan sekolah. Salah satu solusi yang bisa diterapkan untuk mengatasi permasalahan pendidikan adalah berfokus pada proses belajar mengajar. Diperlukan suatu pembelajaran yang aktif kreatif dan menyenangkan sehingga suasana kelas menjadi semakin lebih menarik, tidak monoton dan menantang bagi siswa.

Menciptakan pembelajaran yang aktif dan kreatif menjadi tantangan yang sulit bagi para guru karena membutuhkan waktu lebih banyak, kesabaran, dan tentunya kreativitas serta ketekunan yang harus selalu dikembangkan. Peran guru menjadi sangat urgen dan penting karena guru adalah tombak utama dalam proses belajar mengajar. Tugas mereka akan semakin kompleks dan dituntut untuk selalu mengembangkan diri serta menciptakan iklim dan suasana belajar yang menumbuhkan kreativitas bagi siswanya, atau bahkan sebaliknya guru juga bisa menciptakan suasana yang tidak menantang, monoton, membosankan dan bahkan mematikan kreativitas siswanya. Oleh karena itu, peran guru menjadi faktor penentu keberhasilan pembelajaran.

Dunia pendidikan perlu lebih menyadari bahwa salah satu hal yang terpenting untuk memupuk kreativitas siswa adalah dengan guru yang kreatif. Guru tersebut harus memiliki keinginan dan tekad yang kuat untuk menjadi pembelajar yang aktif. Artinya bila guru tidak memahami sesuatu, dia mau untuk terus belajar dan mengembangkan ilmunya serta mau untuk selalu bertanya kepada siapapun yang bisa diajak diskusi, sharing ide dan pen- dapat tentang strategi pembelajaran maupun masalah lain yang berkaitan dengan pendidikan. Guru yang cerdas dan kreatif sangat dibutuhkan dalam membentuk siswa yang kreatif, hal ini jelas sangat berkaitan dengan pentingnya keteladanan. Siswa akan lebih menuruti dan menghargai gurunya jika dianggap bisa memberikan contoh atau keteladanan yang patut dicontoh siswanya. Terutama yang berkaitan dengan kreativitas, semakin kreatif seorang guru maka akan lebih mudah bagi guru tersebut untuk menstimulus siswanya untuk lebih kreatif. Mereka juga harus pandai dalam memiliki strategi atau metode belajar apa yang tepat untuk dirteepkan karena setiap siswa dan setiap kelas memiliki karakter dan permasalahan yang berbeda-beda. Ditambah lagi salah satu ciri orang yang kreatif menurut Cambpbell (Mangunhardjana, 2006, p. 42) adalah tidak segera menolak ide atau gagasan baru. Mereka seperti membolak-balik ide atau gagasan itu dan melihat segala unsur serta segi-seginya. Mereka mencari segala unsur yang menarik (interesting) dari ide atau gagasan itu dan mengesampingkan kekurangan-kekurangannya. Orang-orang yang kreatif memiliki sikap bukan hanya mendekati perkara dari segi negative dan positif, tetapi lebih-lebih dari sisi menariknya, interesting-nya. Karena reativitas justru lahir karena mampu mengembangkan segi menarik dari suatu ide, gagasan, pemecahan, cara, kemungkinan baru mengenai perkara itu.

Berdasarkan penelitian yang dilakukan oleh Sumiarti, Kuntoro, \& Sutrisno, (2016, p. 76) bahwa pola praksis pendidikan kreatif-Integratif memiliki tujuan tujuan pendidikan yang berlandaskan filosofi manusia sebagai makhluk yang memiliki tiga aspek: jasmani, akal dan ruhani yang harus dikembangkan menjadi manusia cerdas, kreatif dan berkarakter. Kecerdasan dalam konteks ini adalah ragam kecerdasan berdasar teori $\mathrm{Mu}$ ltiple Intelligences (MI) sehingga anak didik difasilitasi untuk mengenali kecerdasannya masing-masing dan kemudian dikembangkan agar menjadi kreativitas. Kreativitas merupakan kemampuan divergent think-ing yang berciri kemampuan anak untuk menyelesaikan masalah dengan berbagai alternatif jawaban, memiliki kekayaan gagasan/ide/ imajinasi dan dapat menciptakan karya kreatif. Pengembangan kecerdasan dan krea tivitas diintegra- 
sikan dengan pengembangan menjadi manusia yang berkarakter baik/positif.

Jangan sampai seorang guru hanya fokus di jam mengajar saja tanpa memperhatikan strategi yang tepat untuk mengajar. Hal ini jelas berkaitan dengan pengertian mendidik dan mengajar. Seorang guru harus fokus bagaimana agar bisa mendidik yang baik yaitu tidak hanya transfer of knowledge tetapi juga transfer of values dan keterampilan.

Seorang guru yang mampu mendidik secara humanis cenderung memiliki kreativitas yang baik pula, terlebih lagi guru yang kreatif mengindikasikan bahwa guru tersebut adalah guru yang profesional dan memiliki karakter yang kuat, hal ini sependapat dengan Dwiningrum (2016, p. 161) bahwa guru yang mempunyai kemampuan untuk menerapkan prinsip-prinsip pendidikan humanis dalam mengajar di kelas dan mampu untuk menjalankan multiperannya sebagai pendidik profesional. Akuntabilitas profesional diperlukan bagi guru untuk mencerminkan kompetensi dan integritas pendidik yang profesional dan berkarakter. Hal ini masih menjadi tantangan bagi para guru.

Beberapa permasalahan yang muncul di sekolah diantaranya seperti siswa membolos, tidak aktif bertanya di kelas, suka mengantuk dan ramai sendiri dikelas hingga yang paling fatal siswa tidak mau masuk ke kelas pada dasarnya salah satu sebabnya adalah karena kurang kreatifnya guru dan kurang memberikan perhatian untuk menjadikan siswanya sebagai subjek didik. Rata-rata guru masih memposisikan siswanya sebagai objek didik, yang harus mendengarkan apa yang disampaikan guru tetapi kurang memberikan kesempatan untuk berpendapat dan bertanya. Siswa yang sering bertanya masih dianggap sebagai siswa yang "bodoh" padahal semakin aktif siswa bertanya berarti hal positif bagi mereka untuk banyak belajar. Akan tetapi sebaliknya, guru mematikan kreativitas mereka dengan memberikan jawaban yang kurang mendidik sehingga membuat siswa tersebut enggan untuk bertanya lagi. Walaupun tidak semua demikian, akan tetapi hal ini perlu menjadi perhatian khusus bagi para pendidik agar lebih berhati-hati dalam memberikan komentar maupun dalam mengartikan makna "aktif dan kreatif" bagi para siswa.

Kerja sama dengan orang tua, masyarakat dan stakeholder sangat diperlukan untuk mensukseskan program kreativitas ini. Hal ini mengingat sekolah dan guru tidak bisa hanya bekerja sendiri, mealinkan sangat memerlukan bantuan dan dukungan dari berbagai pihak agar program membuat siswa kreatif bisa lebih maksimal diupayakan.

Kreativitas menurut Rake (Dwiningrum, 2017) secara operasional berarti membangun masyarakat yang berpandangan bahwa kreatif itu "bagus", menjadikan kreativitas sebagai kebiasaan. Oleh karena itu, seorang guru yang membentuk kreativitas siswa dapat melakukan dengan: (a) menumbuhkan kemampuan siswa untuk membangun masa depan yang lebih baik; (b) menumbuhkan rasa percaya diri; (c) menumbuhkan rasa mampu mengubah keadaan; (d) meminta kreativitas siswa; (e) menyediakan peluang berbuat kreatif; (f) menumbuhkan semangat belajar dan mengetahui serta mencoba hal-hal baru; (g) Toleran terhadap kesalahan.

Pertanyaan yang muncul dalam diri kita adalah sejauhmana proses pendidikan kita sudah mengkondisikan kepada anak-anak kita untuk tumbuh dan berkembang menjadi individu-individu yang berkepribadian kreatif? Sebuah tantangan bagi dunia pendidikan dan tanggung jawab semua orang yang peduli dengan anak bangsa. Satu hal yang perlu dipikirkan juga bahwa kreativitas akan berkembang secara maksimal jika didukung oleh kebudayaan creativogenic, yaitu kebudayaan yang menunjang, memupuk, dan memungkinkan perkembangan kreativitas. Study Gray sebagaimana dikutip oleh Arieti (Munandar, 2002, pp. 176-181) mengemukakan sembilan faktor sosiokultural yang creativogenic, yakni: (1) tersedianya sarana kebudayaan, (2) keterbukaan dan rangsangan, (3) penekanan pada "becoming", (4) memberi kesempatan untuk bebas terhadap media kebudayaan bagi semua warga tanpa diskriminasi, (5) timbulnya kebebasan atau paling tidak hanya ada diskriminasi ringan setelah pengalaman tekanan dan tindakan yang keras, merupakan tantangn terhadap pertumbuhan kreativitas, 6) keterbukaan terhadap rangsangan kebudayaan yang berbeda, bahkan yang kontras, (7) toleransi dan minat terhadap pandangan yang divergen, (8) in-teraksi antar pribadi-pribadi yang berarti, dan (9) insentif, penghargaan dan hadiah. Sebagai catatan, meskipun kebudayaan creativogenic tidak menjadi jaminan untuk mencetak pri-badi-pribadi kreatif, tetapi tugas kita da- 
lam bagaimana mengondisikan faktor-faktor di atas agar hambatan-hambatan dalam proses pengembangan kreativitas siswa dapat diminimalkan.

Pembelajaran yang kreatif sangat ditentukan oleh sekolah yang kreatif dan pastinya guru yang kreatif, oleh karena itu perlu adanya strategi dan indikator yang jelas terkait dengan bagaimana cara mengembangkan sekolah kreatif sebagai upaya perbaikan mutu sekolah tertutama untuk sekolah dasar.

Definisi Pendekatan Sekolah Kreatif: Sebuah komunitas sekolah yang mengembangkan sesuatu yang baru, yang berbeda, dan pendekatan kreatif yang mendukung peningkatan prestasi dan menutup kesenjangan prestasi untuk semua terdaftar siswa. Sebagai contohnya dari kajian yag dilakukan oleh ahli pendidikan, beberapa kriteria yang dibutuhkan oleh sekolah yang mengembangkan pendekatan sekolah kreatif meliputi : (1) aspek desain pendekatan kreatif yakni dengan menggerakan semua komponen sepertihalnya staf, keluarga dan masyarakat; membangun rasionalisasi dengan dukungan data untuk menyusun desain; menciptakan artikulasi program yang dipertahankan oleh sekolah; mengindentifikasikan rencana desain untuk meningkatkan prestasi siswa; mengidentifikasikan progam secara detail dengan membuat kriteria yang jelas untuk target pencapaiannya; dan membuat instumen penilaian efektivitas pencapaian tujuan sekolah. (2) aspek masyarakat dimulai dengan adanya partisipasi luas dari keluarga dan anggota masyarakat dalam mengembangkan desain; berkolaborasi dengan staf untuk menentukan bagaimana staf, keluarga dan anggota masyarakat akan berpartisipasi dalam desain program dan pemantauan keberhasilannya; berkolaborasi dengan staff untuk mengidentifikasi kepemimpinan dan tata kelola struktur untuk sekolah. (3) Aspek Staf yakni semua staf dapat bekerja optimal perminggu; mendukung semua program yang sudah dirancang; berkolaborasi dengan keluarga dan masyarakat untuk menentukan bagaimana staf, keluarga dan anggota masyarakat akan berpartisipasi dalam desain program dan pemantauan yang keberhasilan; berkolaborasi dengan keluarga dan masyarakat untuk mengidentifikasi kepemimpinan dan tata kelola struktur untuk sekolah (QAE - Creative Approach School Information, n.d.).
Berdasarkan latar belakang tersebut, maka penelitian terkait dengan pengembangan indikator sekolah kreatif penting untuk dilakukan dengan tujuan dapat menggali bagaimana indikator sekolah kreatif di sekolah dasar. Oleh karena itu, penelitian ini bertujuan untuk mendiskripsikan indikator sekolah kreatif di SD Muhammadiyah 16 Surabaya (Sekolah Kreatif)

\section{METODE PENELITIAN}

Penelitian ini dirancang dengan pendekatan kualitatif deskriptif. Penelitian kualitatif mendeskripsikan dalam bentuk kata-kata dan Bahasa mengenai apa yang dialami oleh subjek penelitian misalnya perilaku, persepsi, dan tindakan dalam konteks alamiah dengan metode alamiah (Moleong, 2010, p. 6).

Penelitian ini dilaksanakan pada bulan September 2017 di SD Muhammadiyah 16 Surabaya (Sekolah Kreatif). Subjek dalam penelitian ini adalah sekolah kreatif di SD Muhammadiyah 16 Surabaya (sekolah kreatif) dan diwakili oleh Kepala sekolah dan guru.

Teknik pengumpulan data dilakukan dengan wawancara, partisipasi aktif, observasi, FGD, dokumentasi, menggali data terkait. Analisis data penelitian dengan menggunakan reduksi, kategori data sesuai dengan tema-tema yang akan digali dalam penelitian ini. Analisis data yang digunakan adalah analisis kualitatif dimanfaatkan untuk data-data kualitatif. Keabsahan data dalam penelitian ini adalah triangulasi sumber dan triangulasi teknik.

\section{HASIL PENELITIAN DAN PEMBAHASAN}

\section{Profil Sekolah Unggulan}

Berdasarkan data telah dikembangkan dengan dialog teori-teori yang terkait dengan konsep pengembangan sekolah kreatif sesuai dengan konteks masyarakat Indonesia sehingga menemukan formulasi yang lebih tepat. Penelitian ini di lakukan di Sekolah Kreatif (SD Muhammadiyah 16 Surabaya). SD Muhammadiyah 16 Baratajaya Surabaya (Sekolah Kreatif) tidak pernah memilih siswa sejak mulai diresmikan tahun 2002. Sehingga siapapun boleh menjadi siswa di sekolah ini termasuk ABK walaupun belum ada keputusan yang menyatakan bahwa SD muhammadiyah 16 Baratajaya Surabaya (Sekolah Kreatif) adalah sekolah inklusi. Minat masyarakat un- 
tuk menyekolahkan anak-anaknya ke sekolah ini sangat tinggi bahkan sampai inden. Siswa merasa bahagia dan bebas berekspresi tetapi tetap dalam pengawasan para ustad/dzah (panggilan untuk guru di sekolah tersebut). Pihak pengelola sekolah sangat yakin bahwa sekolah yang baik bukanlah sekolah yang memilih siswa mana yang boleh masuk dan tidak boleh masuk, tetapi sekolah yang baik adalah sekolah yang tidak membeda-bedakan setiap input siswa yang mendaftar tanpa memandang sisi akademis, materi maupun non-akademis saja, setiap anak berhak mendapatkan perhatian dan pendidikan yang terbaik. Setiap ustad/ dzah sudah memiliki mindset yang sama yaitu setiap siswa adalah anak yang baik dan hanya perlu diberi perhatian, kasih sayang dan pengarahan.

Selain siswa yang tidak dipilih-pilih, sekolah SD muhammadiyah 16 Baratajaya Surabaya (Sekolah Kreatif) juga tidak mempermasalahkan program studi para gurunya. tidak ada diskriminasi bagi para guru karena mindset yang tertanam adalah setiap orang bisa berubah dan berproses. Guru yang baik adalah guru yang selalu mau belajar dan berproses ke arah yang lebih baik, selalu berusaha membuat kreativitas yang baru. Sila kreativitas yang dikembangkan di SD Muhammadiyah 16 Baratajaya Surabaya (Sekolah Kreatif) adalah yang tidak bersinggungan dengan norma dan hukum. Selama kreativitas itu baik dan memiliki manfaat maka tidak menjadi masalah bagi sekolah.

Sekolah mempunyai peran penting dalam membentuk kepribadian siswa. Sekolah mempunyai peran penting dalam proses sosialisasi. Sosialisasi sebagai proses penting dalam kehidupan manusia, karena dengan sosialisasi maka manusia akan memiliki berbagai tujuan penting bagi individu, keluarga dan masyarakat. Tujuan sosialisasi secara umum antara lain adalan disiplin, aspirasi, indentitas dan peran (Dwiningrum, 2017, pp. 70-71). Dengan demikian, sekolah mempunyai peran penting dalam membangun konsep diri siswa, karena proses sosialisasi menguatkan eksistensi siswa dalam menjalankan peran sosialnya.

Hasil penelitian ini membuktikan bahwa sekolah sebagai lembaga formal terbukti mempunyai peran penting sebagai agen sosialisasi yang penting bagi pengembangan keperibadian siswa yakni terkait dengan peran sekolah dalam membangun konsep diri, Pem- belajaran Edutainment (perpaduan antara $E d u$ cation dan Entertainment), aplikasi edutainment, serta guru dan shadow teacher yang kreatif.

\section{Peran Sekolah dalam Membangun Konsep Diri}

Konsep diri yang dipakai oleh sekolah adalah anak yang memanfaatkan masa kanak-kanak secara maksimal maka akan bahagia dewasanya. Hal ini yang membuat SD muhammadiyah 16 Baratajaya Surabaya (Sekolah Kreatif) membebaskan guru dan siswanya berekspresi dan kreatif. Karena pihak sekolah memahami bahwa selama ini pendidikan di Indonesia rata-rata masih terlalu instruksional dan kurang fleksible terhadap siswa. Yang terpenting dari pendidikan adalah keteladanan, sekolah selalu berusaha memberikan keteladanan dalam mendidik, misalnya ketika ustad/dzah ingin siswanya kreatif maka ustad/dzah harus mengajarkan tentang kreativitas dalam mendidik. Tidak cukup hanya sebatas teori dan perintah, tetapi yang terpenting adalah proses belajar yang terjadi di sekolah. Sehingga tidak ada alasan bagi ustad/dzah untuk tidak melakukan sesuatu dan berkreasi. Ustad-ustadzah dilarang mencela dengan kalimat negatif, karena siswa lebih dominan di imajinatif.

\section{Pembelajaran Edutainment (perpaduan antara Education dan Entertainment)}

Proses pembelajaran penting dalam mendukung proses sosialisasi di sekolah. Pembelajaran akan mengembangkan potensi dan kemampuan siswa dengan optimal, jika dikondisikan dalam budaya sekolah yang positif. Pembelajaran yang menyenangkan akan mendorong siswa untuk belajar aktif dan kreatif.

Konsep belajar dapat dipahami dari dua pendekatan yakni pendekatan perilaku dan pendekatan kognitif (Dahar, 2002, pp. 65-66). Sekolah dalam proses sosialisasi dalam proses pembelajarannya menggunakan dua pendekatan secara sinergis.

Hasil penelitian menggambarkan bahwa sekolah mencoba untuk menerapkan dua pendekatan tersebut secara aplikatif dengan metode yang variatif, sehingga siswa belajar dengan senang dalam proses belajar mengajar dan aktif belajar di kelas. 
Adapun beberapa strategi yang digunakan untuk pembelajaran edutaintment adalah dengan menggunakan pendekatan Somatic, Auditory, Visual dan Intelectual (SAVI).

1) Somatic berarti learning by moving and doing (belajar dengan bergerak dan berbuat).

2) Auditory adalah learning by talking and learning (belajar dengan berbicara dan mendengarkan).

3) Visual diartikan learning by observing and picturing (belajar dengan mengamati dan menggambarkan).

4) Intelectual maksudnya adalah learning by problem solving and reflecting (belajar dengan pemecahan masalah).

Berdasarkan strategi belajar mengajar di atas, dapat dikelompokkan ke dalam hierarki belajar Gagne (Dahar, 2002, pp. 67-68) yaitu:

1) Belajar konsep konkret dengan prosedur membuat respon yang sama pada stimulus-stimulus dengan atribut yang mirip: somantic

2) Belajar tanda (sinyal) dengan prosedur conditioning klasik: auditory

3) Pemecahan masalah dengan menggabungkan aturan untuk mencapai suatu pemecahan yang menghasilkan suatu aturan dengan tingkat lebih tinggi: intelectual

Pelajaran dikemas dalam suasana bermain dan bereksperimen sehingga suasana kelas tidak lagi membosankan, tetapi merupakan arena bermain yang menyenangkan bagi anak.

\section{Aplikasi Edutainment}

Perilaku belajar menentukan hasil belajar. Begitu pula dengan budaya belajar yang diterapkan di sekolah juga menentukan hasil belajar siswa. Ada beberapa strategi pembelajaran yang bisa diterapkan dalam konteks Ilmu Sosial dan Budaya Dasar (Siswoyo, 2017, p. 9) di sekolah, diantaranya:

- Proses pembelajaran diselenggarakan secara interaktif, inspiratif, menyenangkan, menantang, memotivasi peserta didik untuk berpartisipasi aktif serta memberikan ruang yang vukup bagi prakarsa, kreativitas dan kemandirian, dengan menempatkan mahasiswa sebagai subjek pendidikan, mitra dalam proses pembelajaran, dan sebagai anggota keluarga, masyarakat dan warga negara serta warga dunia.

- Pembelajaran yang diselenggarakan merupakan proses yang mendidik yang didalamnya terjadi pembahasan kritis, analitis, induktif, deduktif dan reflektif melalui dialog kreatif partisipatori untuk mencapai pemahaman tentang kebenaran substansi dasar kajian, berkarya nyata, dan untuk menumbuhkan motivasi belajar sepanjang hayat

- Bentuk aktivitas proses pembelajaran kuliah tatap muka, ceramah, dialog (diskusi) interaktif, studi kasus, penugasan mandiri, tugas membaca seminar kecil dan kegiatan ko- kurikuler

Sehubungan dengan strategi di atas, aplikasi edutainment merupakan proses belajar yang lebih menekankan pada aspek perilaku belajar siswa untuk lebih konkret, sehingga hasilnya lebih mudah dipahami oleh siswa.

Adapun bentuk aplikasi edutainment yang diterapkan di sekolah adalah:

- Belajar melalui bermain (mengajak anak untuk menggunting atau melipat, membentuk dan memberi warna) sehingga terbentuk gambar atau model kesukaannya sesuai dengan tema yang dibacakan.

- Setelah emosi anak teraspirasikan melalui kegiatan tersebut, baru mengerjakan materi pelajaran sesuai dengan tema atau pokok bahasan yang dibahas.

- Mengenal benda (objek) secara konkret, sehingga pembelajaran di luar kelas sangat penting.

- Materi pembelajaran didesain secara tematik dan integratif

- Memberikan ruang gerak dan daya nalar yang cukup kepada anak

- Guru tidak diperkenankan marah, tidak berlaku hukuman fisik dan pembelajaran berlangsung asik dan menyenangkan.

\section{Guru dan Shadow Teacher yang Kreatif}

Guru yang kreatif adalah guru yang mampu menghasilkan siswa yang kreatif. Guru yang kreatif termasuk guru yang profesional. Sehingga guru yang profesional merupakan guru yang baik yaitu guru yang senantiasa berusaha untuk menjadi lebih baik serta merekonstruksi pengalamannya dan memperkaya pengalamannya dengan berbagai informasi 
yang dapat mendukung para siswanya agar sukses dalam hidupnya. Menurut Combs (Siswoyo, 2017, pp. 28-29) seorang guru yang baik setidaknya memiliki 26 ciri, diantaranya adalah memiliki rasa humor, memiliki ketulusan hati dan kejujuran, memiliki kasih sayang, kreatif, memiliki kepedulian dan seterusnya.

Menurut Usman (Uno \& Mohamad, 2011, p. 153) menyatakan bahwa guru yang professional adalah orang yang memiliki kemampuan dan keahlian khusus dalam bidang keguruan, sehingga ia mampu melakukan tugas dan fungsinya sebagai guru dengan kemampuan yang maksimal. Kreativitas adalah salah satu kata kunci yng perlu dilakukan guru untuk memberikan layanan pendidikan yang maksimal sesuai kemampuan dan keahlian khusus dalam bidang keguruan. Sebagaimana menjadi guru yang kreatif.

Depdiknas (Uno \& Mohamad, 2011, pp. 145-147) mengemukakan bahwa belajar dengan menggunakan lingkungan memungkinkan siswa menemukan hubungan yang sangat bermakna antara ide-ide abstrak dan penerapan praktis di dalam konteks dunia nyata, konsep dipahami melalui proses penemuan, pemberdayaan, dan hubungan. Secara garis besar, konsep pembelajaran dengan menggunakan lingkungan me-miliki beberapa kelebihan, antara lain sebagai berikut:

- Peserta didik dibawa langsung ke dalam dunia yang konkret tentang penanaman konsep pembelajaran, sehingga peserta didik tidak hanya bisa untuk mengkhayalkan materi.

- Mudah untuk dicerna untuk oleh peserta didik karena peserta didik disajikan materi yang sifatnya konkret bukan abstrak.

- Motivasi belajar siswa akan lebih bertambah karena peserta didik mengalami suasana belajar yang berbeda dari biasanya.

- Konsep yang diajarkan tidk akan terkesan monoton.

- Peserta didik akan lebih leluasa dalam berfikir dan cenderung untuk memikirkan materi yang diajarkan karena materi yang diajarkan telah tersaji di depan mata (konkret).

Menurut shadow teacher, yang dimaksud dengan kreatif adalah bagaimana shadow teacher bisa menangani permasalahan setiap siswa $\mathrm{ABK}$ yang ditanganinya, hal ini karena suasana hati setiap siswa $\mathrm{ABK}$ akan berubah setiap harinya, mereka harus melihat perubahan positif apa yang dilakukan siswa ABK, kemudian membuat laporan kemajuan siswa ABK untuk orang tua dan sekolah dengan menggunakan kalimat positif dan mudah dipahami orang tua, membuat soal yang sesuai kemampuan siswa ABK.

Selain shadow teacher, yang di harus kreatif adalah guru. Semua guru dituntut membuat suasana kelas menyenangkan, tetap tertib tetapi siswa bebas berekspresi dan tidak membeda-bedakan siswa. Misalnya ketika mengajari siswa membaca, tidak harus langsung diberikan buku atau kertas yang penuh dengan tulisan tetapi awalnya diberikan gambar berupa runtutan cerita ditambah dengan tulisan yang mudah dipahami dan dibaca bersama-sama selanjutnya gambar tersebut diwarnai sesuai dengan keinginan siswa. Hal ini lebih mudah dipahami dan menyenangkan siswa. Selain itu tugas PR yang diberikan kepada siswa bukan berupa PR mengerjakan soal berupa tulisan, akan tetapi mereka bebas berekspresi dan boleh dibantu oleh orang tua karena tujuannya agar orang tua juga ikut berperan dalam anak belajar serta menjalin kedekatan emosional antara anak dengan orang tua.

Misalnya pekerjaan rumahnya bertemakan memancing, siswa ada yang membuat gambar ikan dan diwarnai, ada yang membuat kliping tentang memancing, miniatur bentuk ikan dan sebagainya. Hal ini sangat menyenangkan bagi siswa dan membuat mereka berfikir lebih kreatif. Contoh lainnya misalnya siswa kelas 2 memiliki materi tentang keselamatan memadamkan api. Kegiatan diisi dengan outing ke kantor petugas pemadam kebakaran untuk belajar langsung tentang segala sesuatu yang berkaitan dengan pemadam kebakaran. Kegiatan outing dilakukan 3 kali dalam satu tahun dan kegiatan outbound dilakukan 1 kali dalam setahun, selalin itu sekolah juga mendatangkan guru tamu seperti dokter hewan, penjual jamu dan lain-lain.

\section{Aplikasi Portofolio, Tematik dan Fasilitas}

Aplikasi portofolio, tematik dan fasilitas adalah wadah untu memberikan apresiasi terhadap anak yang rajin membaca, hal ini dilakukan dengan ada jadwal khusus untuk 
berkunjung ke perpustakaan untuk meningkatkan minat literasi siswa. Sekolah mengajarkan minat literasi sejak kelas 1, diantaranya dengan menceritakan tentang teladan para rasul, kisah kebaikan seseorang yang akhirnya berujung keberuntungan dan kebahagiaan sehingga siswa termotivasi untuk membaca sekaligus sebagai salah satu strategi penanaman nilai moral. Siswa diminta untuk membuat cerita, boleh dibantu oleh orang tua dengan berbagai cara yang kreatif, misalnya membuat cerita tidak harus dalam bentuk tulisan tetapi bisa membuat lampion, assesories dan sebagainya sehingga lebih menarik ketika akan bercerita di depan kelas. Kegiatan tersebut biasanya dilakukan setiap hari senin, dengan beberapa kegiatan sebagai berikut:

- Pembelajaran disusun secara tematik dan integratif

- Pekerjaan anak (LKS) secara variatif dan kreatif dengan banyak memanfaatkan kertas.

- Subtema diterapkan setiap minggu sekali.

- Buku paket tidak wajib, buku bacaan anak, science, agama dan lain-lain disediakan di perpustakaan.

- Setiap kelas terdapat perpustakaan mini, komputer, dan rak folder siswa.

- Hasil pekerjaan siswa, setelah dipajangkan di kelas kira-kira 2-3 minggu, dimaksudkan ke dalam folder. Setelah diperiksa guru hasil kerja anak tersebut (folder) ditunjukkan kepada orang tua melalui siswa atau meeting orang tua sekurang-kurangnya tiap bulan.

\section{Teknik Evaluasi}

Teknik evaluasi bertujuan untuk mengetahui sejauh mana pencapaian prestasi anak yang sudah mereka usahakan di sekolah. Oleh karena itu diperlukan cara yang tepat untuk melakukan evaluasi yang benar-benar bisa menilai kemampuan siswa secara menyeluruh, tidak hanya fokus pada nilai kuantitaif semata akan tetapi juga mencakup secara kualitatif.

Fungsi evaluasi (Purwanto, 2013, p. 5) dalam pendidikan dan pengajaran dapat dikelompokkan menjadi 4 fungsi, yaitu:

- Untuk mengetahui kemuan dan perkembangan serta keberhasilan siswa setelah mengalami atau melakukan kegiatan belajar setelah mengalami dan melakukan kegiatan belajar selama jangka waktu ter- tentu. Hasil evaluasi yang diperroleh itu selanjutnya dapat digunakan untuk memperbaiki cara belajar siswa (fungsi formatif) dana tau untuk mengisi rapor atau surat tanda tamat belajar, yang berarti pula unntuk menentukan kenaikan kelas atau lulus-tidaknya, yang berarti pula untuk menentukan kenaikan kelas atau lulus tidaknya seorang siswa dari suatu lembaga pendidikan tertentu (fungsi sumatif)

- Untuk mengetahui tingkat keberhasilan program pengajaran. Pengajaran sebagai suatu sistem terdiri atas beberapa komponen yang saling berkaitan satu sama lain. Komponen-komponen dimaksudkan antara lain adalah tujuan, materi, atau bahan pengajaran, metode dan kegiatan belajar mengajar, alat dan sumber pengajaran, dan prosedur serta alat evaluasi.

Untuk melakukan suatu evaluasi bisa diawali dengan pengumpulan data atau informasi yang dilaksanakan setiap akhir pelaksanaan pembelajaran untuk materi sajian yang berkenaan dengan satu kompetensi dasar dengan maksud guru dan siswa memperoleh gambar menyeluruh dan kebulatan tentang pelaksanaan pembelajaran yang telah dilaksanakan untuk pencapaian penguasaan satu kompetensi dasar (Widoyoko, 2010, p. 20).

Berdasarkan hasil penelitian, teknik evaluasi yang dilakukan disekolah dilakukan secara terpadu yaitu dilaksanakan secara kuantitatif, juga leadership dan kepribadian dalam bentuk narasi. Perkembangan setiap anak juga diamati secara cermat.

\section{Kiat-Kiat yang Diterapkan sehingga Sekolah menjadi Unggul atau Maju}

Setiap sekolah pasti memiliki strategi atau kiat untun kemcapai aka yang menjadi tujuan sekolah tersebut. Dalam hal ini yang menjadi tujuan adalah kiat untuk menjadikan sekolahnya memiliki keunggulan dan semakin maju dari sebelumnya.

Berdasarkan hasil penelitian, beberapa kiat yang sudah dilakukan oleh SD $\mathrm{Mu}-$ hammadiyah 16 Baratajaya Surabaya (Sekolah Kreatif) diantaranya adalah:

a. Mempunyai konsep yang jelas: konsep Edu-tainment (Pendidikan yang dikemas dengan suasana yang menyenangkan dan bermakna) 
b. Sekolah Inklusi: menerima siswa berkebutuhan khusus setiap kelasnya ada 2 siswa (menanamkan rasa empati kepada siswa yang mempunyai kekurangan)

c. Kelas kecil dengan jumlah 25-28 siswa didampingi 2 guru (memberikan perhatian lebih kepada siswa)

d. Pendekatan secara individual bukan klasikal (pemberdayaan, menggali dan mengembangkan potensi yang ada pada setiap siswa/multiple intelegent)

e. Up grade kemampuan dan skill SDM (Pelatihan/workshop/studi banding/magang untuk guru dan karyawan)

f. Kerjasama dengan Komite Sekolah (Pentas Seni, Family Gathering, Seminar $P a-$ renting, Bhakti Sosial, Guest Teacher)

g. Pelayanan yang prima (ramah, perhatian, peduli kepada siswa, orang tua dan masyarakat sekitar)

h. Team work yang solid

i. Mengutamakan proses daripada hasil

j. Memiliki Tim Inovasi Pengembangan Sekolah/TIPS

\section{Reward dan Punishment}

Reward (hadiah) dan Punishment (hukuman) diperlukan untuk memotivasi anak dalam melakukan hal positif, terumana hadiah dan hukuman yang bersifat mendidik. Menurut Munandar (2002, p. 163), hadiah untuk pekerjaan yang dilaksanakan dengan baik tidak harus berupa materi (intangible). Yang terbaik justru berupa senyuman atau anggukan, kata penghargaan, kesempatan untuk menampilkan dan mereprresentasikan pekerjaan sendiri, dan pekerjaan tambahan. Jika iklim kelas sedemikian rupa sehingga belajar menjadi menarik dan menyenangkan, pekerjaan tambahan dapat merupakan hadiah. Hadiah yang diberikan hendakya berkaitan erat dengan kegiatannya, misalnya mendeklamasikan sajak yang dibuat, atau membacakan di depan kelas karangan yang dibuat dengan baik, sehingga meningkatkan motivasi intrinsic dan kreativitas.

Berkaitan dengan hal di atas, SD Muhammadiyah 16 Baratajaya Surabaya (Sekolah Kreatif) selalu memberikan apresiasi kepada siswa yang melakukan hal yang positif sekecil apapun. Setiap hal positif yang berhasil dicapai siswa akan dihitung oleh wali kelas, misalnya jika siswa berbuat baik ke te- mannya, siswa tersebut akan diberikan kertas bertuliskan hal baik yang dilakukannya tersebut dan akan ditempelkan di baju anak selama seharian penuh. Hal ini sangat kreatif karena siswa merasa setiap kebaikannya dihargai dan diapresiasi secara positif oleh warga sekolah termasuk siswa yang lain. Hal ini dapat memunculkan rasa ingin melakukan kebaikan dan hal positif setiap hari. Untuk reward, dapat dirangkum sebagai berikut:

- Reward diberikan kepada setiap siswa yang melakukan hal yang positif atau bisa merubah perilaku menjadi lebih baik.

- Pemberian reward setiap minggu (harinya menyesuaikan kelas masing-masing) dan dirayakan.

- Setiap orang yang melihat (guru, karyawan, orang tua) harus memberi apresiasi kepada siswa/anak tersebut.

- Ketika siswa sudah mengumpulkan 10 reward maka akan mendapat 1 Sertifikat Ten Reward

- Ketika siswa sudah mengumpulkan 5 Sertifikat Ten Reward akan mendapat $1 \mathrm{Me}-$ dali Perunggu

- Ketika siswa sudah mengumpulkan 3 Perunggu akan mendapat 1 Medali Perak.

- Ketika siswa sudah mengumpulkan 2 Medali Perak akan mendapat 1 Medali Emas

\section{Sekolah Kreatif}

Pengembangan sekolah kreatif bukan pekerjaan yang mudah. Akan tetapi sebagai proses sosial yang membutuhkan beberapa persiapan bagi sekolah. Sekolah akan kreatif membutuhkan 6 aspek di atas yaitu: peran sekolah dalam membangun konsep diri, pembelajaran edutainment, aplikasi edutainment dan guru dan shadow teacher yang kreatif, aplikasi portofolio, tematik dan fasilitas dan teknik evaluasi. Di samping itu, untuk mengembangkan sekolah kreatif perlu didukung oleh beberapa aspek: pengembangan sistem gagasan dan ide, pengembangan sistem sosial dalam aktivitas belajar, penciptaan sistem lingkungan sekolah yang sinergis antar unsur sekolah

1. Pengembangan Sistem Gagasan dan Ide

a. Sekolah membangun masyarakat yang berpandangan bahwa kreatif itu "pen-ting" bagi kehidupan manusia

b. Sekolah menjadikan kreativitas sebagai kebiasaan 
c. Guru mampu menciptakan iklim atau suasana belajar yang menumbuhkan kreativitas atau sebaliknya mematikan kreativitas

d. Guru memberikan kesempatan kepada siswa untuk berekspresi

e. Guru menanamkan konsep "becoming"

f. guru tidak diskriminasi terhadap perbedaan budaya

g. Sekolah mengajarkan kepada siswa untuk menghargai perbedaan budaya

h. Guru menanamkan kesetaraan, multikutural dan demokrasi

i. Sekolah memberi motivasi kepada siswa untuk bebas berekspresi dan menujukkan eksistensi.

2. Pengembangan sistem sosial dalam aktivitas belajar

a. Guru menumbuhkan rasa percaya diri

b. Guru menumbuhkan rasa mampu mengubah keadaan menjadi lebih baik

c. Guru mengembangkan kreativitas siswa sesuai dengan minat

d. Guru menumbuhkan semangat belajar dan mengetahui serta mencoba hal-hal baru. Hal ini sesuai dengan visi misi sekolah yaitu

e. Siswa dibiasakan menghargai pendapat dan kreativitas yang berbeda

f. Siswa dimotivasi untuk mendukung keberhasilan visi dan misi sekolah

g. Siswa mempunyai program aktivitas yang terkait dengan budaya, sains dan olah raga di sekolah dan di luar sekolah

3. Penciptaan sistem lingkungan sekolah yang sinergis antar unsur sekolah Aspek Desain Sekolah

a. Sekolah mendesain lingkungan yang kreatif dan inovatif

b. sekolah mengidentifikasi rencana desain dan prestasi siswa secara bertahap

c. sekolah merancang program secara detail dalam program semesteran dan tahunan

d. sekolah membuat instument penilaian untuk evaluasi

Aspek Masyarakat

a. Sekolah mendorong partisipasi luas dari keluarga dan anggota ma- syarakat dalam mengembangkan desain

b. sekolah berkolaborasi dengan staf untuk menentukan bagaimana staf, keluarga dan anggota masyarakat akan berpartisipasi dalam desain program dan pemantauan keberhasilannya

c. guru berkolaborasi dengan staf untuk mengidentifikasi kepemimpinan dan tata kelola struktur untuk sekolah

Aspek Staf

a. Staf mendukung semua program yang sudah dirancang

b. staf berkolaborasi dengan keluarga dan masyarakat untuk menentukan bagaimana staf

c. staf menjalin hubungan keluarga dan anggota masyarakat akan berpartisipasi dalam desain program dan pemantauan yang keberhasilan

\section{SIMPULAN}

Berdasarkan hasil penelitian dan pembahasan yang telah dipaparkan, maka dapat ditarik kesimpulan sebagai berikut. Dalam membentuk sekolah yang efektif dan kreatif diperlukan beberapa point penting yang harus dimiliki dan selalu dikembangkan oleh sekolah, diantaranya untuk membuat sekolah lebih kreatif dapat dilakukan dengan 6 aspek dan 3 indikator. 6 aspek tersebut yaitu peran sekolah dalam membangun konsep diri, pembelajaran edutainment, aplikasi edutainment dan guru dan shadow teacher yang kreatif, aplikasi portofolio, tematik dan fasilitas dan teknik evaluasi. 3 indikator yang bisa diterapkan disekolah yaitu pengembangan sistem gagasan dan ide, pengembangan sistem sosial dalam aktivitas belajar dan penciptaan sistem lingkungan sekolah yang sinergis antar unsur sekolah.

\section{DAFTAR PUSTAKA}

Dahar, R. W. (2002). Teori-teori belajar dan pembelajaran. Jakarta: Penerbit Erlangga.

Dwiningrum, S. I. A. (2016). Menciptakan belajar yang humanis tantangan pendidik 
yang profesional dan berkarakter. Jurnal Pembangunan Pendidikan: Fondasi Dan Aplikasi, 4(2), 154.

https://doi.org/10.21831/jppfa.v4i2.1242 0

Dwiningrum, S. I. A. (2017). Sketsa teori persekolahan. Yogyakarta: UNY Press.

Mangunhardjana, A. M. (2006).

Mengembangkan kreativitas.

Yogyakarta: Kanisius.

Moleong, L. J. (2010). Metodologi penelitian kualitatif. Bandung: Remaja Rosdakarya Offset.

Munandar, U. (2002). Kreativitas dan keberbakatan. Jakarta: Gramedia Pustaka Utama.

Purwanto, M. N. (2013). Prinsip-prinsip dan teknik evaluasi pengajaran. Bandung: PT Remaja Rosdakarya.

QAE - Creative Approach School Information. (n.d.). No Title. Retrieved
March 25, 2017, from http://qaecas.weebly.com/cas-definition-criteria.html

Siswoyo, D. (2017). Sekolah dan guru dalam tantangan jaman. Yogyakarta: UNY Press.

Sumiarti, S., Kuntoro, S. A., \& Sutrisno, S. (2016). Pola pendidikan cerdas kreatif berkarakter; praksis di rumah kreatif Wadas Kelir Purwokerto Jawa Tengah. Jurnal Pembangunan Pendidikan: Fondasi Dan Aplikasi, 4(1), 67. https://doi.org/10.21831/jppfa.v4i1.9821

Uno, H. B., \& Mohamad, N. (2011). Belajar dengan pendekatan PAILKEM. Jakarta: Bumi Aksara.

Widoyoko, S. E. P. (2010). Evaluasi program pembelajaran. Yogyakarta: Pustaka Pelajar. 